\title{
Erratum to: Networking Activities and Perceptions of HIV Risk Among Male Migrant Market Vendors in China
}

\section{Wenqing Wang · Kathryn E. Muessig •}

Mingqiang Li $\cdot$ Ying-Xia Zhang

Published online: 13 February 2014

(C) Springer Science+Business Media New York 2014

\section{Erratum to: AIDS Behav}

\section{DOI 10.1007/s10461-013-0473-5}

Unfortunately, the name of the last author was incorrect in the original publication. The author name has been corrected in this erratum.

The online version of the original article can be found under doi:10.1007/s10461-013-0473-5.

W. Wang Department of Social Work, Beijing Institute of Technology, Beijing, China

K. E. Muessig $(\square)$

School of Medicine, University of North Carolina at Chapel Hill, 130 Mason Farm Road, Bioinformatics Building, CB\#7030, Chapel Hill, NC 27599, USA

e-mail: kmuessig@med.unc.edu

M. Li · Y.-X. Zhang

Liuzhou Center for Disease Prevention and Control, Liuzhou,

China 